\title{
Dynamics of the Accumulation of Essential Oils in the Roots of Ferula foetida (Bunge) Regel) Depending on the Age and Place of Growth in the Mangistau Region (the Western Kazakhstan)
}

\author{
Akzhunis Imanbayeva ${ }^{1 *}$, Meruert Sagyndykova ${ }^{1}$, and Margarita Ishmuratova $^{1}$ \\ ${ }^{1}$ Mangyshlak Experimental Botanical Garden of Science Committee of Ministry of Education and \\ Science of Republic of Kazakhstan, $10^{\text {th }}$ micro district, 100000, Aktau, Kazakhstan
}

\begin{abstract}
For the first time, the dynamics of the accumulation of essential oil in the underground organs of Ferula foetida grown on the territory of the Mangistau region (the Western Kazakhstan), depending on the age of the plant and the place of growth, are investigated. The maximum accumulation of essential oil is noted for the 4 th year of vegetation $(0.98 \%)$, the minimum - for the annual plants $(0.14 \%)$. The largest quantitative composition of essential oil is noted in the sands of Tuyesu and on the elevation of Tynymbay Shoky, the minimum - in the vicinity of the Karkol wintering. As the results of the study the optimal places of raw materials harvesting and collection dates are determined.
\end{abstract}

\section{Introduction}

The herbs are the valuable source of biologically active substances, which are the basis for the production of medicinal preparations. In Kazakhstan, wild flora resources are underutilized. So, from the more than 1000 species of plants used in folk medicine [1], only 160 taxa have been introduced into official using [2].

The important herb of the Mangystau region, which has prospects for its use, is the smelly ferula (Ferula foetida (Bunge) Regel). The raw material of this species exhibits antispasmodic and anticonvulsant properties, is used in the treatment of asthma, a number of nerve diseases, dyspepsia, diarrhea, diabetes mellitus, pulmonary tuberculosis, cerebral atherosclerosis, kidney diseases, syphilis and diseases of the intestinal tract [2-9].

For any medicinal plant the study of dynamics of accumulation of biologically active substances is very important, since it allows assessing the optimal period for gathering of raw materials.

\footnotetext{
Corresponding author, imangarden@mail.ru
} 
The purpose of the present study is to determine the quantitative accumulation of essential oils in the underground organs of Ferula foetida depending on the age of the plant and the place of growth.

\section{Materials and methodology}

\subsection{Vegetative raw materials}

Root samples of different age (Fig. 1) are taken during expeditions (sands of Tuyesu, Maykomgen, Karynzharyk, Tynymbai Shoky upland, the vicinity of the Karkol wintering and Burma Mount) in 2018-2019 (Table 1).

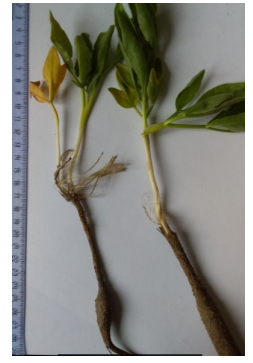

1-year individuals

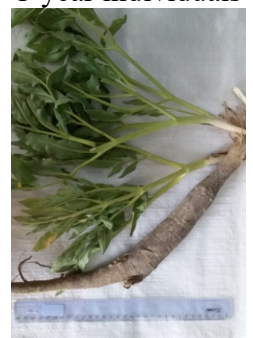

5-year individuals
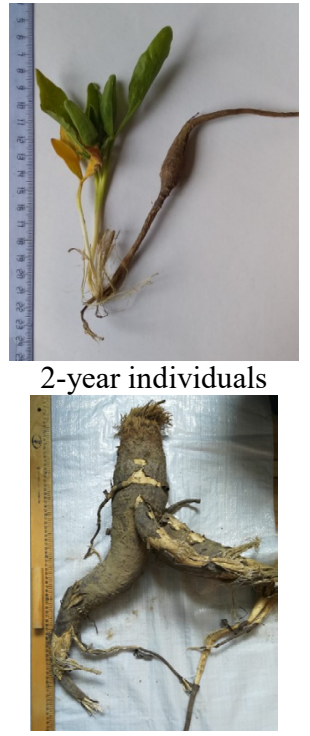

6-year individuals

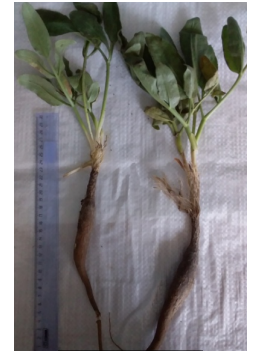

3-year individuals

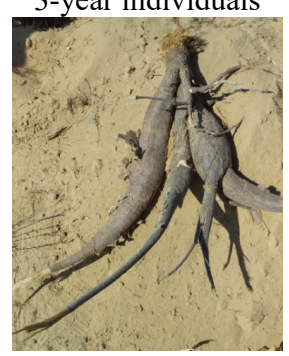

7-year individuals

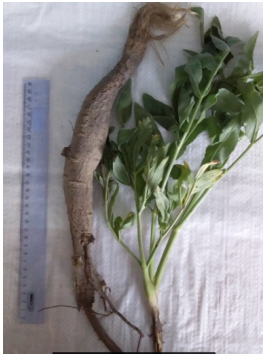

4-year individuals

Fig. 1. Samples of vegetative raw materials of Ferula foetida of the different ages

Table 1. Places of selection of raw materials of Ferula foetida in the Mangistau region

\begin{tabular}{|l|c|c|c|}
\hline \multirow{2}{*}{ Geographic point } & \multicolumn{3}{|c|}{ GPS-coordinates } \\
\cline { 2 - 4 } & Northern latitude & East longitude & $\begin{array}{c}\text { Height above sea } \\
\text { level, meter }\end{array}$ \\
\hline \multirow{3}{*}{ Sands Tuyesu } & & 53.30573 & 91.2 \\
\cline { 2 - 4 } & 43.20438 & 53.34322 & 79.5 \\
\cline { 2 - 4 } & 43.20372 & 53.36392 & 68.0 \\
\cline { 2 - 4 } & 43.20413 & 53.36555 & 68.0 \\
\hline \multirow{2}{*}{$\begin{array}{l}\text { Sandy massifs near the Karkol } \\
\text { wintering }\end{array}$} & 45.38331 & 54.55117 & 9.8 \\
\cline { 2 - 4 } & 45.47166 & 54.32572 & 19.1 \\
\hline \multirow{2}{*}{ Sands Maykomgen } & 45.38441 & 54.55072 & -20.0 \\
\cline { 2 - 4 } & 46.35317 & 54.13156 & 110.0 \\
\hline Sands Karynzharyk & 47.20308 & 54.21111 & 82.7 \\
\cline { 2 - 4 } & 43.00335 & 54.01450 & 88.5 \\
\hline The vicinity of Burma Mount & 42.56053 & 54.05538 & 53.0 \\
\hline
\end{tabular}




\begin{tabular}{|l|c|c|c|}
\hline Tynymbai Shoky upland & 43.17376 & 53.43135 & 142.0 \\
\cline { 2 - 4 } & 43.19422 & 53.40188 & 51.7 \\
\cline { 2 - 4 } & 43.17431 & 53.43325 & 92.0 \\
\cline { 2 - 4 } & 43.17384 & 53.45464 & 107.0 \\
\hline
\end{tabular}

\subsection{Extraction of essential oil}

Quantitative determination of essential oils was carried out by hydro distillation method with following volume-weight analysis of the obtained product $[10,11]$.

\section{Results}

Ferula foetida refers to monocarpic herbs living in the arid conditions [12]. In wild, the species grows up to 5-7 years, after a single flowering it dies.

The results of the quantitative determination showed that trace amounts of essential oil accumulate in the above-ground organs of Ferula foetida, which makes the grass unsuitable as a source of this type of biologically active substances. The quantitative accumulation of essential oils in roots by age is shown on figure 2 .

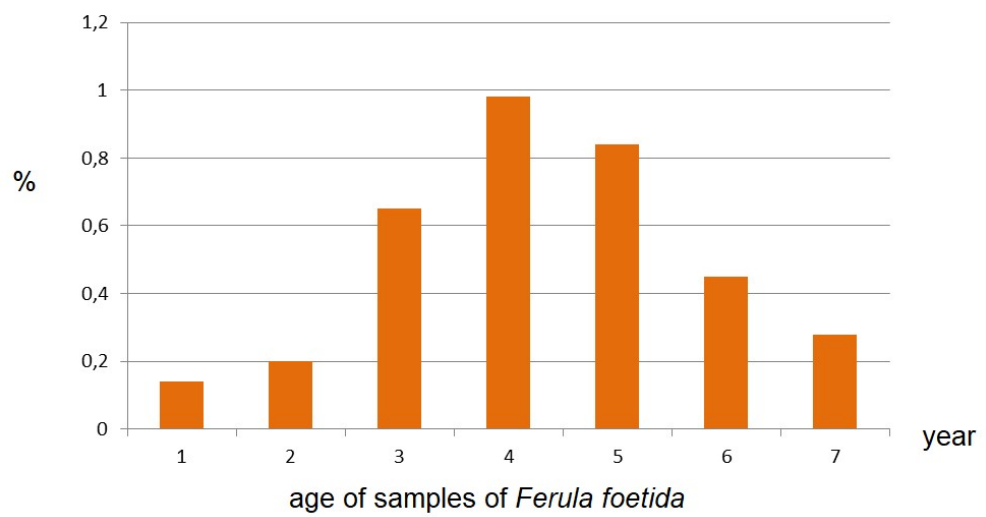

Fig. 2. Dynamics of essential oil accumulation in Ferula foetida roots depending on plant age

Data of quantitative accumulation of essential oil depending on places of collection are given in table 2.

Table 2. Results of quantification of essential oil content in roots of Ferula foetida depending on age and place of gathering

\begin{tabular}{|l|c|c|c|}
\hline \multicolumn{1}{|c|}{ Place of gathering } & $\begin{array}{c}\text { Age of individ- } \\
\text { uals }\end{array}$ & Sample & $\begin{array}{c}\text { Quantitative content of essential } \\
\text { oil on dry weight, \% }\end{array}$ \\
\hline Sands Tuyesu & 4 years & Roots & 0.98 \\
\cline { 2 - 4 } & 5 years & Roots & 0.61 \\
\cline { 2 - 4 } & 6 years & Roots & 0.84 \\
\cline { 2 - 4 } & 7 years & Roots & 0.32 \\
\hline \multirow{4}{*}{$\begin{array}{c}\text { Tynymbai Shoky up- } \\
\text { land }\end{array}$} & 4 years & Roots & 0.65 \\
\cline { 2 - 4 } & 5 years & Roots & 0.70 \\
\cline { 2 - 4 } & 6 years & Roots & 0.65 \\
\hline \multirow{2}{*}{$\begin{array}{c}\text { The vicinity of Karkol } \\
\text { wintering }\end{array}$} & 5 years & Roots & 0.73 \\
\cline { 2 - 4 } & 6 years & Roots & 0.09 \\
\hline
\end{tabular}




\begin{tabular}{|l|l|l|l|}
\hline & 7 years & Roots & 0.28 \\
\hline \multirow{3}{*}{ Sands Maykomgen } & 6 years & Roots & 0.45 \\
\cline { 2 - 4 } & 7 years & Roots & 0.14 \\
\hline \multirow{3}{*}{ The vicinity of Burma } & 4 years & Roots & 0.87 \\
\cline { 2 - 4 } & 6 years & Roots & 0.52 \\
\cline { 2 - 4 } & 7 years & Roots & 0.22 \\
\hline \multirow{3}{*}{ Sands Karynzharyk } & 5 years & Roots & 0.20 \\
\cline { 2 - 4 } & 6 years & Roots & 0.55 \\
\cline { 2 - 4 } & 7 years & Roots & 0.28 \\
\hline
\end{tabular}

\section{Discussion}

The results of quantitative determination showed that in underground organs the accumulation of essential oil ranged from 0.09 to $0.98 \%$. Analysis by age shows that in 1-year samples the quantitative accumulation of essential oil was $0.14 \%$, in the 2 -year the growth until $0.2 \%$ is observed, in the third year - until $0.65 \%$. The maximum is noted for 4-year individuals $-0.98 \%$, after which there is a gradual decline in the accumulation of essential oil. So, for 5 -year individual was $0.84 \%$, for 6 -years was $0.45 \%$, for 7 -year was $0.28 \%$. This fact can be explained that the Ferula foetida for 5-7 years of vegetation usually goes into a generative state, after which the plant dies, which leads to a decrease in the accumulation of some compounds.

Analysis of different collection points showed a high variation of data. Sands Tuyesu were the most favorable habitat for Ferula foetida with maximum essential oil accumulates in roots - from 0.32 to $0.98 \%$. The second position is occupied by Ferula foetida populations on the Tynymbai Shoky uplands, in which the quantitative accumulation of essential oil was $0.65-0.73 \%$. The third position is occupied by individuals from the vicinity of Burma Mount - $0.22-0.87 \%$. The minimum accumulation of essential oil is recorded in the Sands Maykomgen for 7-year-old plants $(0.14 \%)$ and for sands in the vicinity of the Karkol wintering in 6-year-old individuals $(0.09 \%)$. Analysis of the quantitative content of essential oil in various places of growth also confirms the maximum accumulation for individuals of 4-6 years of age.

Based on the data obtained, it can be noted that for each population of Ferula foetida, the accumulation of essential oil in the roots depends on the place of growth.

This data indicate that for obtain of essential oil, 4-5-year-old Ferula foetida individuals should be harvested as the source of raw material. The biggest accumulation of essential oil is noted in the Sands Tuyesu and on Tynymbai Shoky uplands.

The work was carried out with the support of the state grant of the Committee of Science of the Ministry of Education and Science of the Republic of Kazakhstan (AP05130892).

\section{References}

1. L.M. Grudzinskaya, N.G. Gemedzhiieva, N.V. Nelina, Zh.Zh. Karzhaubekova, Annotated list of herbs of Kazakhstan (Almaty, 2014)

2. The State Pharmacopeia of Republic of Kazakhstan (Astana, 2010)

3. T.M. Zubajdova, D.N. Dzhamshedov, S.D. Isupov, I.A. Zagrebel'nyj, Bulletin of Tajik National University. Series of Natural Science. 1-3, 225-229 (2014)

4. M.H. Abd El-Razek, Biosci. Biotechnol. Biochem. 71, 2300-2303 (2007)

5. A.S. Abu-Zaiton, Pak. J. Biol. Sci. 15, 97-100 (2010)

6. A. Amalraj, S.J. Gopi., Tradit. Complement. Med. 7, 347-359 (2016) 
7. G. Appendino, E. Mercalli, N. Fuzzati, L. Arnoldi, M. Stavri, S. Gibbons, M. Ballero, A. Maxia, J. Nat. Prod. 67, 2108-2110 (2004)

8. H.G. Saidova, G.H. Kodirova, I.D. Karomatov, Biology and Integrative Medicine. 3, 58-70 (2017)

9. T.M. Zubajdova, D.N. Dzhamshedov, M. Hodzhimatov, M.N. Nazaro, S.D. Isu-pov, I.A. Zagrebel'nyj, N.YU. Samandarov, P.SH. Suhrobov, Bulletin of Tajik National University. Series of Natural Science. 1-2, 205-213 (2013)

10. R.A. Muzychkina, D.YU. Korul'kin, ZH.A. Abilov, Technology of production and analysis of phytopreparations (Kazak University, Almaty, 2011)

11. Yu.A. Litvinenko, Methodological manual for laboratory works for the discipline "Chemistry of natural biologically active substances and phytopreparations" (Kazak University, Almaty, 2012)

12. L.K. Safina, M.G. Pimenov. Ferula of Kazakhstan (Nauka, Alma-Ata, 1984) 